\title{
BRITISH STILLBIRTHS AND FIRST WEEK DEATHS, 1950-57
}

\author{
BY
}

\author{
T. M. ALLAN
}

Royal Infirmary, Aberdeen

It is well known that in the 1950 s the incidence of stillbirths has continued to fall in Scotland but has stopped falling in England and Wales (e.g. Heady and Heasman, 1959). Here the incidence is studied with reference to sex, with an unexpected result, as is that of first week deaths. The sources of the data are the Annual Reports of the Registrar General for Scotland (1950-57) and the Statistical Reviews of the Registrar General for England and Wales (1950-57). As in the report of the Biological and Medical Committee of the Royal Commission on Population (1950), a comparison is made with the corresponding Netherlands figures, and a similar comparison is made with the Danish figures.

\section{SCOTLAND}

\section{Sex Ratio of Stillbirths}

Sutherland (1949) pointed out that in Scotland the sex ratio of stillbirths fell from 1939, the year in which they first became registrable. This trend was reversed in 1947 (Table I), but was then resumed, until in 1956 and 1957 the sex ratio of Scottish stillbirths was lower than that of Scottish live births. In both these years the Scottish live birth sex ratio was $1 \cdot 06$.

\section{ENGLAND AND WALES}

Sutherland (1949) pointed out that in England and Wales the sex ratio of stillbirths fell from 1928, the year in which they first became registrable. This fall stopped in 1938 (Table I), but began again in 1952. The remarkable steadiness of the stillbirth sex ratio in England and Wales in 1939-51 stands in very striking contrast to the two-wave fall in the Scottish stillbirth sex ratio which occurred during the same period (Table I). Unfortunately no attempt can be made to find the reasons for this potentially illuminating contrast, as the causes of stillbirths in England and Wales are not registered.
TABLE I

SEX RATIO OF BRITISH STILLBIRTHS, 1938-57

\begin{tabular}{|c|c|c|c|c|c|c|}
\hline \multirow{3}{*}{$\begin{array}{c}\text { Year of } \\
\text { Occurrence } \\
\text { of Stillbirths }\end{array}$} & \multicolumn{6}{|c|}{ Legitimate plus Illegitimate Stillbirths } \\
\hline & \multicolumn{3}{|c|}{ England and Wales } & \multicolumn{3}{|c|}{ Scotland } \\
\hline & Male & Female & $\begin{array}{l}\text { Ratio } \\
\mathbf{M}: \mathbf{F}\end{array}$ & Male & $\overline{\text { Female }}$ & $\begin{array}{l}\text { Ratio } \\
\mathbf{M}: \mathbf{F}\end{array}$ \\
\hline 1938 & 13,349 & 11,380 & $1 \cdot 17$ & & & \\
\hline 1939 & 13,105 & 11,204 & $1 \cdot 17$ & 2,112 & 1,720 & $1 \cdot 23$ \\
\hline 1940 & 12,296 & 10,483 & $1 \cdot 17$ & 2,117 & 1,682 & $1 \cdot 26$ \\
\hline 1941 & 11,268 & 9,608 & $1 \cdot 17$ & 2,065 & 1,628 & $1 \cdot 27$ \\
\hline 1942 & 11,868 & 10,515 & $1 \cdot 13$ & 1,956 & 1,645 & $1 \cdot 19$ \\
\hline 1943 & 11,469 & 9,793 & $1 \cdot 17$ & 1,835 & 1,657 & $1 \cdot 11$ \\
\hline 1944 & 11,493 & 9,813 & $1 \cdot 17$ & 1,741 & 1,477 & $1 \cdot 18$ \\
\hline 1945 & 10,367 & 8,966 & $1 \cdot 16$ & 1,518 & 1,427 & 1.06 \\
\hline 1946 & 12,357 & 10,558 & $1 \cdot 17$ & 1,808 & 1,673 & 1.08 \\
\hline 1947 & 11,792 & 10,003 & $1 \cdot 18$ & 1,912 & 1,645 & $1 \cdot 16$ \\
\hline 1948 & 9,937 & 8,462 & $1 \cdot 17$ & 1,575 & 1,391 & $1 \cdot 13$ \\
\hline 1949 & 9,129 & 7,818 & $1 \cdot 17$ & 1.402 & 1,261 & $1 \cdot 11$ \\
\hline 1950 & 8,693 & 7,391 & $1 \cdot 18$ & 1,319 & 1,237 & 1.07 \\
\hline 1951 & 8,669 & 7,316 & $1 \cdot 18$ & 1,292 & 1.186 & 1.09 \\
\hline 1952 & 8,368 & 7,268 & $1 \cdot 15$ & 1,249 & 1,180 & 1.06 \\
\hline 1953 & 8,311 & 7,370 & $1 \cdot 13$ & 1,197 & 1,107 & 1.08 \\
\hline 1954 & 8,467 & 7,733 & 1.09 & 1,243 & 1,157 & 1.07 \\
\hline 1955 & 8,303 & 7,526 & $1 \cdot 10$ & 1,229 & 1,098 & $1 \cdot 12$ \\
\hline 1956 & 8,609 & 7,796 & $1 \cdot 10$ & 1,170 & 1,156 & 1.01 \\
\hline 1957 & 8,613 & 8,002 & 1.08 & 1,195 & 1,183 & 1.01 \\
\hline
\end{tabular}

\section{Sex Incidence of Stillbirths}

\section{ENGLAND AND WALES}

That the sex ratio of stillbirths in England and Wales fell from 1952 onwards, after having been stationary since 1938 , is very largely due to one fact. This is that, while the male legitimate stillbirth rate in England and Wales was slightly lower in 1954-57 
as a whole than in 1950-53 as a whole, the female legitimate stillbirth rate was higher in each of the 4 years from 1954 to 1957 than in any of the previous 4 years (Table II), and was indeed higher even in 1957 than in any year from 1947 to 1953 . These secular differences, like others mentioned here, are too large to be due to simple binomial chance fluctuations in the proportions (Brass, 1959), and it is interesting to compare their trend with that of the corresponding rates for the Netherlands (Table II). (In the Netherlands stillbirths are counted from the 26th week, in Britain from the 28th week.) Moreover in England and Wales the female illegitimate stillbirth rate was higher in 1956 and 1957 than in any other year since 1948. Unfortunately, the absence of registration of the causes of stillbirths in England and Wales precludes the possibility of identifying the cause or causes responsible for the rise.

\section{SCOTLAND}

The male and female stillbirth rates in Scotland were both considerably lower in 1954-57 than in 1950-53 (even so they were still considerably higher than the rates for England and Wales), but from 1953 onwards the female stillbirth rate fell only minimally-from 24.5 per 1,000 female births in 1953 to $24 \cdot 2$ per 1,000 female births in 1957. In Denmark the legitimate female stillbirth rate was 16.4 in 1950 53 and $16 \cdot 5$ in $1954-57$.

\section{Sex Incidence of First Day Deaths}

\section{SCOTLAND}

The death rate in the first 24 hours after birth in Scotland was slightly lower for females in 1954-57 as a whole than in 1950-53 as. a whole, but in 3 of the 4 years from 1954 to 1957 the male first day death rate was higher than in any of the previous 4 years. In Scotland, unlike England and Wales, the number of deaths in the first 30 minutes after birth and in the rest of the first day respectively are not recorded separately.

\section{ENGLAND AND WALES}

In England and Wales the male and female death rates in the first 30 minutes after birth were both considerably lower in 1954-57 as a whole than in $1950-53$ as a whole. The death rate from 30 minutes to 24 hours after birth was higher for males in 3 of the 4 years from 1954 to 1957 than in any of the previous 4 years and was also very slightly higher for females in 1954-57 as a whole than in 1950-53 as a whole (Table III, opposite).

In the Netherlands there was a continued fall throughout 1954-57 in the proportion both of male and female babies dying on the same calendar day as that on which they were born (Table III). That the rise in the first day death rate in England and Wales was much greater in males is of special interest in view of the fact that the rise in the stillbirth rate was confined to females.

TABLE II

LEGITIMATE FEMALE STILLBIRTHS IN ENGLAND AND WALES AND IN THE NETHERLANDS, 1950-57

\begin{tabular}{|c|c|c|c|c|c|c|}
\hline \multirow{3}{*}{$\begin{array}{l}\text { Year of Occurrence } \\
\text { of Legitimate Stillbirths }\end{array}$} & \multicolumn{3}{|c|}{ Netherlands } & \multicolumn{3}{|c|}{ England and Wales } \\
\hline & \multirow{2}{*}{$\begin{array}{l}\text { Legitimate } \\
\text { Female } \\
\text { Live Births } \\
\text { +Stillbirths }\end{array}$} & \multicolumn{2}{|c|}{ Legitimate Female Stillbirths } & \multirow{2}{*}{$\begin{array}{l}\text { Legitimate } \\
\text { Female } \\
\text { Live Births } \\
\text { + Stillbirths }\end{array}$} & \multicolumn{2}{|c|}{ Legitimate Female Stillbirths } \\
\hline & & $\begin{array}{l}\text { Absolute } \\
\text { Number }\end{array}$ & $\begin{array}{c}\text { Per } 1,000 \\
\text { Legitimate } \\
\text { Female Births }\end{array}$ & & $\begin{array}{l}\text { Absolute } \\
\text { Number }\end{array}$ & $\begin{array}{c}\text { Per } 1,000 \\
\text { Legitimate } \\
\text { Female Births }\end{array}$ \\
\hline 1950 & 111,519 & 2,090 & $18 \cdot 7$ & 328,113 & 6,916 & $21 \cdot 1$ \\
\hline 1951 & 110,880 & 1,975 & $17 \cdot 8$ & 319,860 & 6.847 & $21 \cdot 4$ \\
\hline 1952 & 112,532 & 1,915 & $17 \cdot 0$ & 318,917 & 6,814 & $21 \cdot 4$ \\
\hline 1953 & 110,760 & 1,878 & $17 \cdot 0$ & 323,505 & 6,930 & $21 \cdot 4$ \\
\hline Aggregate, 1950-53 & 445,691 & $\mathbf{7 , 8 5 8}$ & $17 \cdot 6$ & $1,290,395$ & 27,507 & $21 \cdot 3$ \\
\hline 1954 & 110,798 & 1,840 & $16 \cdot 6$ & 319,149 & 7,307 & $22 \cdot 9$ \\
\hline 1955 & 111,961 & 1,789 & $16 \cdot 0$ & 316,107 & 7,100 & $22 \cdot 5$ \\
\hline 1956 & 112,601 & 1,841 & $16 \cdot 3$ & 331,446 & 7,307 & $22 \cdot 0$ \\
\hline 1957 & 113,937 & 1,854 & $16 \cdot 3$ & 341,705 & 7,491 & $21 \cdot 9$ \\
\hline Aggregate, 1954-57 & 449,297 & 7,324 & $16 \cdot 3$ & $1,308,407$ & 29,205 & $22 \cdot 3$ \\
\hline
\end{tabular}


TABLE III

FIRST DAY DEATHS IN ENGLAND AND WALES AND IN THE NETHERLANDS, 1950-57

\begin{tabular}{|c|c|c|c|c|c|c|c|c|}
\hline \multirow{3}{*}{$\begin{array}{l}\text { Year of Occurrence } \\
\text { of First Day Deaths }\end{array}$} & \multicolumn{4}{|c|}{$\begin{array}{c}\text { Deaths in the Netherlands on the Calendar Day of } \\
\text { Birth }\end{array}$} & \multicolumn{4}{|c|}{$\begin{array}{c}\text { Deaths in England and Wales between } 30 \text { minutes } \\
\text { and } 24 \text { hours after Birth }\end{array}$} \\
\hline & \multicolumn{2}{|c|}{ Absolute Number } & \multicolumn{2}{|c|}{ Per 1,000 Live Births } & \multicolumn{2}{|c|}{ Absolute Number } & \multicolumn{2}{|c|}{ Per 1,000 Live Births } \\
\hline & Male & Female & Male & Female & Male & Female & Male & Female \\
\hline 1950 & 936 & 676 & $7 \cdot 9$ & $6 \cdot 1$ & 2,556 & 1,858 & $7 \cdot 1$ & $5 \cdot 5$ \\
\hline 1951 & 907 & 681 & $7 \cdot 7$ & $6 \cdot 2$ & 2,578 & 1,814 & $7 \cdot 4$ & $5 \cdot 5$ \\
\hline 1952 & 842 & 638 & $7 \cdot 1$ & $5 \cdot 7$ & 2,503 & 1,907 & $7 \cdot 2$ & $5 \cdot 8$ \\
\hline 1953 & 891 & 662 & $7 \cdot 6$ & $6 \cdot 0$ & 2,485 & 1,909 & $7 \cdot 1$ & $5 \cdot 7$ \\
\hline Aggregate, $1950-53 \quad$.. & 3,576 & 2,657 & $7 \cdot 6$ & $6 \cdot 0$ & 10,122 & 7,488 & $7 \cdot 20$ & $5 \cdot 64$ \\
\hline 1954 & 837 & 623 & $7 \cdot 1$ & $5 \cdot 6$ & 2,579 & 1,899 & $7 \cdot 4$ & $5 \cdot 8$ \\
\hline 1955 & 785 & 626 & $6 \cdot 7$ & $5 \cdot 6$ & 2,585 & 1,834 & $7 \cdot 5$ & $5 \cdot 7$ \\
\hline 1956 & 740 & 547 & $6 \cdot 2$ & $4 \cdot 9$ & 2,656 & 1,885 & $7 \cdot 4$ & $5 \cdot 5$ \\
\hline 1957 & 611 & 478 & $5 \cdot 1$ & $4 \cdot 2$ & 2,817 & 2,015 & $7 \cdot 6$ & $5 \cdot 7$ \\
\hline Aggregate, 1954-57 & 2,973 & 2,274 & $6 \cdot 3$ & $5 \cdot 1$ & 10,637 & 7,633 & $7 \cdot 48$ & $5 \cdot 68$ \\
\hline
\end{tabular}

Sex Ratio of Deaths in the First Week

\section{ENGLAND AND WALES}

Takahashi (1954) showed that the sex ratio of first week deaths in Japan in 1941-42 and 1947-49and also, according to data of Pfaundler (1942), in Germany-was highest on the third day after birth. In England and Wales, however, in both 1950-53 and $1954-57$, the sex ratio of deaths rose very steeply from birth to the fourth day after birth (Table IV), after which it fell to the seventh day. It is particularly interesting that in England and Wales the sex ratio of deaths in the first $\mathbf{3 0}$ minutes after birth has been lower than that of deaths in the rest of the first day in every year since 1931, when the distinction was first recorded.

\section{SCOTLAND}

The sex ratio of deaths in the first week in Scotland was highest on the third day after birth in 1950-53, and on the fourth day after birth in 1954-57 (Table IV). The sex ratio of deaths fell from the third to the seventh day in 1950-53, and from the fourth to the seventh in 1954-57.

\section{SUMmary}

In England and Wales the sex ratio of stillbirths was virtually stationary from 1938 to 1951 . Since 1952 , however, it has fallen, owing largely to a rise

TABLE IV

SEX RATIO OF BRITISH STILLBIRTHS AND DEATHS IN THE FIRST 4 DAYS OF LIFE

\begin{tabular}{|c|c|c|c|c|c|c|c|c|c|c|}
\hline \multirow{2}{*}{$\begin{array}{l}\text { Country of } \\
\text { Occurrence }\end{array}$} & \multirow{2}{*}{\multicolumn{4}{|c|}{ Time of Occurrence }} & \multicolumn{3}{|c|}{ Deaths in $1950-53$} & \multicolumn{3}{|c|}{ Deaths in 1954-57 } \\
\hline & & & & & Male & Female & $\begin{array}{l}\text { Ratio } \\
\mathbf{M}: \mathbf{F}\end{array}$ & Male & Female & $\begin{array}{l}\text { Ratio } \\
\mathbf{M}: \mathbf{F}\end{array}$ \\
\hline \multirow{6}{*}{ England and Wales } & 4th Day & . & .. & .. & 2,400 & 1,257 & 1.91 & 2,177 & 1,223 & $1 \cdot 78$ \\
\hline & 3rd Day & 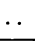 & . & .. & 3,431 & 2,131 & 1.61 & 3,177 & 1,907 & 1.67 \\
\hline & 2nd Day & . & .. & .. & 4.127 & 2,865 & 1.44 & 3,917 & 2,725 & 1.44 \\
\hline & 30 Minute & -24 & ours & .. & 10,122 & 7,488 & $1 \cdot 35$ & 10,637 & 7,633 & $1 \cdot 39$ \\
\hline & First $30 \mathrm{M}$ & inut & . & .. & 1,474 & 1,213 & $1 \cdot 22$ & 1,352 & 1,211 & $1 \cdot 12$ \\
\hline & Stillbirths & . & .. & .. & 34,041 & 29,345 & $1 \cdot 16$ & 33,992 & 31,057 & 1.09 \\
\hline \multirow{5}{*}{ Scotland } & 4th Day & . & $\cdots$ & .. & 265 & 173 & $1 \cdot 53$ & 249 & 139 & $1 \cdot 79$ \\
\hline & 3rd Day & .. &. & .. & 496 & 288 & $1 \cdot 72$ & 490 & 298 & $1 \cdot 64$ \\
\hline & 2nd Day & .. & .. & . & 739 & 539 & $1 \cdot 37$ & 646 & 484 & $1 \cdot 33$ \\
\hline & 1st Day & .. & . & .. & 1,914 & 1,403 & $1 \cdot 36$ & 2,074 & 1,439 & $1 \cdot 44$ \\
\hline & Stillbirths & $\ldots$ & $\ldots$ & . & 5,057 & 4,710 & $1 \cdot 07$ & 4,837 & 4,594 & 1.05 \\
\hline
\end{tabular}


in the female stillbirth rate in 1954-57 compared with 1950-53-a setback accompanied by a rise in the male death rate in the period from 30 minutes to 24 hours after birth. In 1950-57 the sex ratio of deaths in England and Wales rose steeply from birth to the fourth day after birth.

The fact that the female stillbirth rate and the male first day death rate rose in England and Wales in 1954-57 compared with 1950-53 is contrasted with the fact that in the Netherlands both these rates fell appreciably in 1954-57 compared with 1950-53. Regret is expressed that, in the case of female stillbirths, no attempt can be made to identify the cause or causes responsible for the rise, because the causes of stillbirth in England and Wales are not registered.

I am grateful to Professor P. J. Idenburg, DirectorGeneral of Statistics of the Netherlands Central Bureau of Statistics, and to Dr. H. Hamtoft of the Statistical Section of the Danish National Health Service, for the Netherlands and Danish figures respectively, and to Mr. William Brass for his assessment of the data.

\section{REFERENCES}

Brass, W. (1959). Personal communication

Heady, J. A., and Heasman, M. A. (1959). "Social and Biological Factors in Infant Mortality." General Register Office. Studies on Factors in Infant Mortality." General Register Office. Studies on
Medical and Population Subjects, No. 15. H.M.S.O., London. Pfaundler, M. (1942). Z. Kinderheilk., 63, 1.

Registrar General for England and Wales (1952-1958). "Statistical Review of England and Wales, 1950-57," Tables, Part I, Medical. H.M.S.O., London.

Registrar General for Scotland (1953-1958). "Annual Reports Nos. 96-103 for 1950-57." H.M.S.O.. Edinburgh.

Royal Commission on Population: Biological and Medical Committee (1950). "Reports, Papers of the Royal Commission on mittee (1950). "Reports, Papers of the
Population, vol. IV". H.S.M.O., London.

Sutherland, I. (1949). "Stillbirths: Their Epidemiology and Social Sutherland, I.,"(1949). "Stillbirths: Their Epiden
Significance". Oxford University Press, London.

Takahashi, E. (1954). Hum. Biol., 26, 133.

\section{APPENDIX \\ Incidence of Deaths from the Second to The Seventh Day}

ENGLAND AND WALES. - Both the male and female death rates were lower in 1954-57 than in 1950-53 for each day from the second to the seventh day after birth.

SCotland.-The second day female death rate, after falling from 1950 onwards, rose in 1956 and
1957 , and the third day female death rate was very slightly higher in 1954-57 than in 1950-53. Both the male and female death rates were lower in 1954-57 than in 1950-53 for each day from the fourth to the seventh day after birth. In all these respects the numbers were very small. 